\title{
VALIDATION OF KEY RELATIONSHIPS IN AN EXTENDED SERVICE-PROFIT CHAIN MODEL IN THE SOUTH AFRICA RETAIL INDUSTRY CONTEXT
}

\author{
ANTON M VERWEY \\ LOUIS CARSTENS \\ Dept of Human Resource Management \\ Rand Afrikaans University
}

\begin{abstract}
The purpose of the study was to evaluate an extended conceptual model depicting hypothesised relationships between employee climate, customer value and financial performance. Questionnaires assessing employeeexperienced climate and customer-experienced value were completed by all the employees (more than 1200) and more than 2000 customers of a single retail company operating almost 100 stores in Southern Africa. The major findings were that some of the components of employee-experienced climate are positively related to customerexperienced value in terms of both product and relationship quality. There was no significant relationship between customer-experienced value and the financial performance of the organisation.
\end{abstract}

\section{OPSOMMING}

Die doel van hierdie studie was om ' $\mathrm{n}$ uitgebreide konseptuele model te toets wat gehipotetiseerde verwantskappe voorstel tussen werknemer-ervaarde klimaat, kliënt-ervaarde waarde en finansiële prestasie. Vraelyste wat werknemer-ervaarde klimaat en kliënt-ervaarde waarde meet is voltooi deur meer as 1200 werknemers en meer as 2000 kliënte van ' $n$ enkele kleinhandelaar wat landwyd byna 100 winkels regoor Suid-Afrika bedryf. Die hoofbevindinge is dat sommige komponente van werknemer-ervaarde klimaat positief verwant is aan kliënt-ervaarde waarde in terme van beide produk en verhoudingsgehalte. Daar was egter geen beduidende verband tussen kliëntervaarde waarde en die finansiële prestasie van die organisasie nie.

Given the growing complexities of customer relationships, customer relationship management (CRM) has become a wellknown concept within most modern-day organisations. This is especially true within the service industry and more particularly within branches thereof such as financial services and information technology. One reason for this is that the service industry has come to dominate the global economic landscape. For example, Heard (2002) points out that 64 of the top 100 companies in the 2002 Fortune 500 magazine are service companies. Key issues include defining what precisely is meant by the term 'relationship' in this context and questioning the applicability of CRM in the retail industry, where it might be argued that perceived customer value may be determined to a greater extent by the characteristics of the actual product.

One approach to addressing the issue of customer relationships, as highlighted by Wiersema (1996:7-8), describes companies that have mastered the art of customer intimacy as those that "... analyse their systems, recognise their flaws, challenge their assumptions, and assume responsibility for initiating change. In this transformed market, what counts is the human dimension. Customer intimate companies craft relationships of openness and confidence...". Nalebuff \& Brandenburger (1996:161) suggest that organisations and their customers "... are partners in creating value .. the overall game is co-opetition". What this implies is that business organisations no longer have carte blanche to decide on product qualities, pricing strategies, distribution channels, customer support and other aspects regarding their relationship with customers. Consumers increasingly demand involvement in one form or another in deciding on these issues.

As regards customer involvement, Ling (2000) says "The question is, 'does the customer want to be owned? or does the customer want to own him or herself?' Increasingly, it is the latter. It will be enlightening to see how businesses cope with this". Normann \& Ramirez (1993:69) also suggest that “... a company's principal

Requests for copies should be addressed to: AM Verwey, Department of Human Resource Management, RAU University, PO Box 524, Auckland Park, 2006 strategic task is the reconfiguration of its relationships and business systems". From another perspective, Harris (1998:362) suggests that a marketing culture, characterised by values such as team integration and competitive outcomes, forms the basis for customer orientation throughout the organisation.

In short, business organisations as the intermediaries between employees and customers need to assess and reshape where necessary their relationships with these key stakeholders. To do so effectively and sustainably will by definition require a rethink also of their human capital philosophies, strategies and practices. From the perspective of business organisations, the background sketched above leads to a number of questions, such as:

- What is the relationship, if any, between success as a business and the nature and quality of our relationship with customers?

- What is the relationship, if any, between success as a business and the nature and quality of our relationship with employees?

Given the background and problem statement sketched above, the specific objectives of this study were to:

- Develop an extended conceptual framework of the serviceprofit chain; and

- Validate key elements of this extended service-profit chain within a sector of the retail industry and, more specifically:

- Establish the relationship between customer-experienced value (CEV) and employee-experienced climate (EEC); and

- Determine whether CEV is a driver of store economic performance (revenue and profit).

Given the research objectives as set out above, the following research hypotheses were formulated:

- Stores ranked higher on CEV will also display higher average scores for EEC.

- Stores ranked higher on sales revenue performance as compared to budgeted performance will display higher average scores for CEV. 
- Stores ranked higher on sales revenue performance improvement from year 1 to year 2 will display higher average scores for CEV.

- Stores ranked higher on sales profit contribution performance will display higher average scores for CEV.

- Stores ranked higher on sales profit contribution performance improvement from year 1 to year 2 will display higher average scores for CEV.

\section{ORGANISATIONAL VALUE CREATION}

Key questions on organisational performance are (1) by what criteria is organisational success measured, and (2) is there a specific approach to the achievement of such success?

This section will highlight the concepts of organisational (enterprise) performance and the service-profit chain from a theoretical perspective in order to:

- illustrate that economic measures of enterprise performance may not provide a full picture of sustainable growth;

- highlight some approaches to the achievement of sustainable enterprise performance;

- show that service quality is related to organisational performance; and

- indicate that service is also related to internal processes in the organisation.

\section{Measures of Organisational Performance}

If indeed there is a purpose to organisations beyond pure economics, it would be logical to expect such a purpose to be reflected in the measures applied in assessing whether organisations create value or not. At the same time, as such measures are inherently less objective than purely economic ones, it is also to be expected that there would be much more diverse views on what such measures should be.

From a financial perspective there is general agreement that profit, profitability, market share, market value, revenue, and growth are all valid measures of the overall performance of the organisation. Jensen (2001) argues that attempts to evaluate organisations on measures other than market value detract from their ability to deliver to all stakeholders, and that for this reason business performance should be the sole corporate objective. The term 'value-based management' describes one approach that attempts to extend economic measures beyond the purely tactical level to include dimensions of sustainable growth. Such measures (Miller, 1998:11-12) would include market value added (MVA), which may be defined as market value minus capital invested, and economic value added (EVA), which may be defined as the difference between return on invested capital minus the weighted average cost of capital multiplied by total capital invested. The danger inherent in all such value-based measures is the same as for any other measure of economic performance. Short-term views on the "numbers" may still drive behaviour which detracts from longer-term sustainable performance. The mathematics involved in MVA and EVA will show that both indices can be improved by simply investing less capital in a business. This would clearly not be in the long-term interests of the business. The issue is therefore to a lesser extent one of the actual measure, and rather the degree to which the leadership in the organisation take a longer- or shorter-term view of such measures.

As business moves into the new millennium, the old methods of reporting are proving no longer to be sufficient. New forms of corporate disclosure which integrate financial, environmental and social reporting are starting to take shape. According to Elkington (1997), triple bottom-line reporting is an approach which points to practical benefits for companies themselves as well as for their various stakeholders. While the American and European approach to business ethics is generally oriented towards utility, and individual interest based on the moral responsibility of the individual, an example of more inclusive measures may be found in an approach based on the ethics of Kant, who emphasizes the importance of social partnerships by viewing businesses as social institutions (Fülöp, Hisrich \& Szegedi, 2000:7). This view of business is not a new one. Already in 1981, Peter Drucker (quoted by Bowman \& Wittmer, 2000:15) suggested that business has no special status and that common rules of ethics apply to it. Allee (2000:21) says, "Enterprises and organisations are not only the fabric of larger society, they are in turn dependent on that larger social system", which would suggest that organisations are cocreators also of the rules of ethics to which Drucker refers, and are therefore by definition bound to them.

Kaplan \& Norton (1996) presented the "balanced scorecard" methodology in a Harvard Business Review article entitled, "Using the balanced scorecard as a strategic management system". They point out that, in the business environment, organisations compete on the basis of information, and that an organisation's ability to exploit intangible assets is becoming increasingly more important than its ability to exploit physical assets. The problem, according to these authors, is that most organisations' operational and management control systems are built around financial measures and targets that do not measure the organisation's progress towards achieving long-term strategic objectives. A gap exists between the development of strategy and its implementation. Their solution is to develop a "balanced scorecard" that supplements traditional financial measures with three new perspectives, namely those of the customer, internal business processes, and learning and growth. Further to the additional perspectives on organisational performance, managers must introduce four new processes that contribute to linking long-term strategic objectives with short-term goals (the performance measures):

- translating the vision into actionable plans;

- communicating and linking the efforts throughout the organisation;

- business planning; and

- feedback and learning (Zeigenfuss, 2000:13).

Eccles (1991:137) says the following about organisational performance measurement in balanced scorecard terms:

"We are not simply talking about changing the basis of performance measurement from financial statistics to something else. We are talking about a new philosophy of performance measurement".

Another approach to the definition of organisational results is provided by Obolensky (2000:5), who suggests that, within the context of the inclusive company, "...both hard and soft measures are important - business must measure both its contribution to society and its return for investors". One such a "soft" measure could be corporate reputation, which Caruana (1997:110) describes as follows: "Just as firms have a multitude of publics they also have an array of reputations as each public often considers a different set of attributes. Moreover, even if the same attribute is considered by different publics it may be given a different weighting".

In a similar vein, Handy (1994:225-226) suggests that the following aspects also need to be included in the balance sheets of organisations:

- Intellectual assets (brands, patents, skills base), including expenditure to enhance these assets on, for example, research and development, and training;

- Customers (quality of goods and services, and customer satisfaction); and

- The environment (investment in environmental control and improvement, expenditure on community work, and investment in the community). 
The fundamental learning is that none of the approaches discussed disputes the validity of profit (economic) measures as an indicator of organisational performance. What is very clear is that there is a significant body of thought supporting the view that such measures are not enough, and that they need to be supplemented with dimensions that are more inclusive of the interests of various stakeholder and interest groupings.

\section{Methods of Achieving Organisational Performance: The Service-profit Chain}

An organisation's ability to compete effectively in a particular market is increasingly seen as being dependent on its capacity to deliver offerings which comprise a competitive bundle of benefits, or value, to the consumer (Devlin, 1998:1091). "The issue of highest priority today involves understanding the impact of service quality on profit and other financial outcomes of the organisation" (Zeithaml, Berry \& Parasuraman, 1996:31). This statement represents a dramatic departure from organisational views of quality as recent as a decade ago. In initial explorations within the services arena, quality was primarily viewed as a problem, manifesting at the tactical level, that needed to be solved. Service quality has since emerged as an irrepressible, globally pervasive strategic force (Powell, 1995) as well as a key strategic issue on management's agenda (Dean \& Bowen, 1994). Seen from this perspective, the service-profit chain represents not only a different approach to the question of how businesses achieve excellence, but also a different approach philosophically to the route taken by the business excellence model in getting there. In some part at least, it may be hypothesised that this shift is also a reaction to or a reflection of the increasing importance of service industries compared to manufacturing industries in terms of gross national product, especially in developed countries (Phillip \& Hazlett, 1997:260).

It is important to realise that the fundamental difference between services on the one hand and products on the other is that the consumption of a service is process consumption rather than outcome consumption. When consuming a physical product, customers make use of the product itself, i.e. they consume the outcome of the production process. In contrast, when consuming services, customers perceive the process of producing the service to a larger or smaller degree and also take part in the process. The consumption process leads to an outcome for the customer, which is the result of the service process. Thus, the consumption of the service process is a critical part of the service experience (Grönroos, 1998:322).

In essence, the service-profit chain (SPC) is a model integrating perceived value from three key stakeholder perspectives, i.e. those of customers, shareholders and employees. The serviceprofit chain as formulated by Heskett can be diagrammatically represented as below (Lau, 2000:432; Payne, Holt \& Frow, 2000:264).
In developing this model, Heskett set out the following propositions (Payne et al, 2000:263):

- Profit and growth are stimulated primarily by customer loyalty;

- Customer loyalty is a direct result of customer satisfaction;

- Customer satisfaction is largely influenced by the value of services (external service value) provided to customers;

- External service value is created by satisfied, loyal (retained) and productive employees; and

- Employee satisfaction is the result of high-quality support services and policies that enable employees to deliver results to customers (internal service quality).

What is also suggested through this diagram is that the marketing culture of the organisation (the organisational process of creating an external identity and "presence" for itself and its products or services) is directly related to the internal organisational culture (Harris, 1998:355-360).

The SPC model contains at least two potential "gaps", these being the internal service quality gap and the external service quality gap. Particularly in terms of the latter, a significant volume of research has been conducted. A key aspect of the external service value gap is customers' determination process for perceived service quality. Expected service and perceived service are both directly influenced by the determinants of service quality, which finally determine the overall level of service quality (Parasuraman et al, 1985).

Initially, ten different dimensions to the external service quality gap were identified. These were access, communication, competence, courtesy, credibility, reliability, responsiveness, security, tangibles, and customer knowledge. Through further research these ten dimensions were consolidated into five (Parasuraman et al, 1988), leading to the development of SERVQUAL, a 22-item scale designed to measure service quality. The five dimensions of the scale are tangibles, reliability, responsiveness, assurance, and empathy.

In terms of external service quality, Sureshchandar, Rajendran \& Anantharaman (2002:33) contend that SERVQUAL does not address other important constituents of service quality such as the service product or core service, the systematisation and standardisation of service delivery, and the social responsibility of the organisation. Other criticism of the SERVQUAL instrument centers on both theoretical and operational levels, ranging from item formulation to scale construction (Philip \& Hazlett, 1997:269-272; Robinson, 1999:21). Robinson (1999:29) later concludes that "as a result it is questionable whether SERVQUAL is a reliable measure of service quality or, indeed, whether it is measuring service quality at all". Despite the criticism, though, SERVQUAL continues to be one of the most widely recognised methods of measuring service quality (Newman, 2001:129).

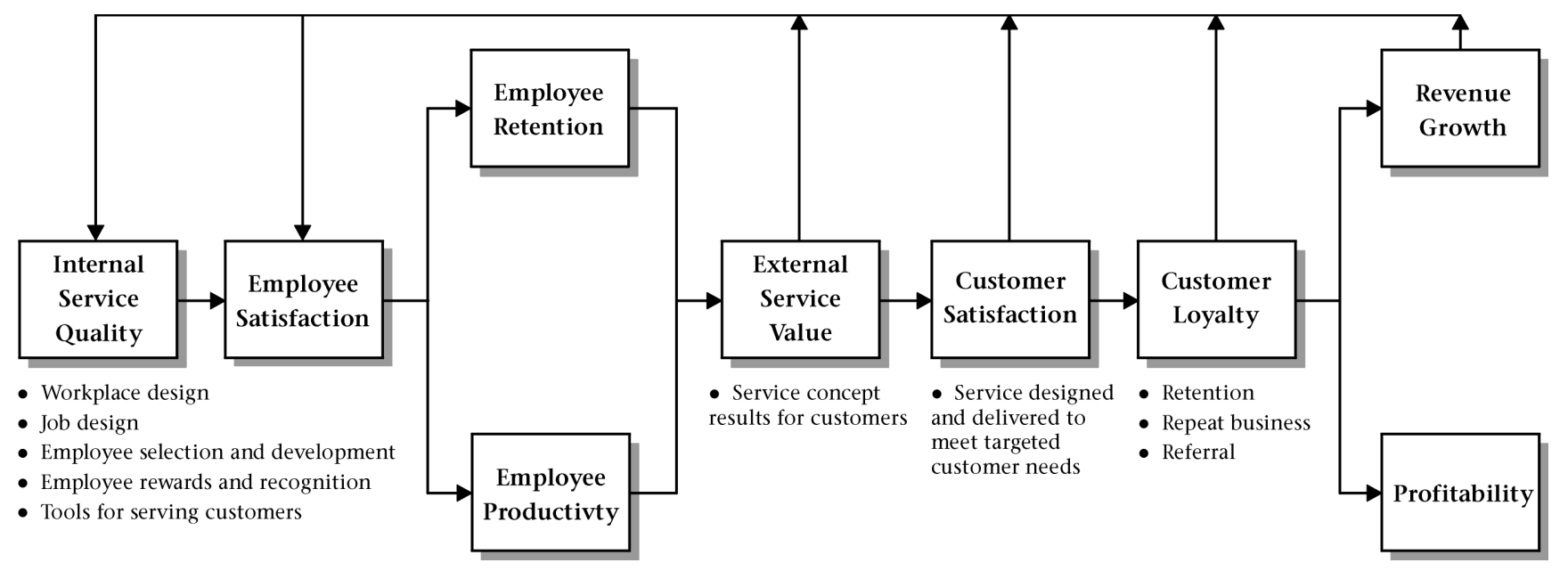

Figure 1: Service-profit Chain 
Other research related to the service-profit chain covers a variety of topics.

- From a perspective of strategic benchmarking, Soteriou \& Zenios (1999) developed a framework guided by the serviceprofit chain for combining strategic benchmarking with efficiency benchmarking of the services offered by a bank. Three models were developed in order to implement the framework in a practical setting: (i) an operational efficiency model, (ii) a service quality efficiency model, and (iii) a profitability efficiency model.

- Imrie, Cadogan \& McNaughton (2002) showed the need to view the drivers and determinants of customer value within a particular cultural context.

- Cuthbert (1996a; 1996b) assessed the usefulness of the SERVQUAL instrument within the setting of higher education.

- Mehta \& Durvasula (1998) and Durvasula, Lyons \& Mehta (1999) applied SERVQUAL within an industrial marketing situation.

- Parasuraman (1998) proposed an intriguing agenda for research within the business-to-business market, while Grönroos, Heinonen, Isoniemi \& Lindholm (2000) indicated that, regardless of whether products or goods are purchased through the internet, the notion of service is still inherent to such transactions, and developed a model for the development of internet-based offerings.

- Huber, Hermann \& Wricke (2001) found through empirical research that price acceptance (i.e. a price premium) is indeed related to customer satisfaction, while the research of Caruana, Money \& Berthon (2000) explored the relationship between service quality, customer value and customer satisfaction.

- Silvestro \& Cross (2000:254) applied the service-profit chain model in a retail environment, and found that their research results "lend a surprising degree of support for the service-profit chain model".

- Pitt, Caruana \& Berthon (1996) developed an instrument to assess the relationship between market orientation and business performance, whilst Parasuraman et al (1991, 1993, 1994) also reported further refinements to the SERVQUAL instrument.
Research on the SPC and SERVQUAL would thus appear to focus on a number of different but related areas, such as:

- The societal context (cultural);

- The industry context; and

- Specific and extended links to the SPC model, which provides support to the overall approach taken to this study.

Finally, Silvestro \& Cross (2000:246) suggest that the strength of the model (the integration of various performance drivers) is also its weakness, as it makes for a complex model which can easily be disproved.

The service-profit chain had its origins in the increasing importance of service rather than product consumption. While product quality could be assessed easily and perhaps even objectively, the intangibility of services made it almost impossible to do so. It is suggested though that this distinction has become an artificial and academic one. Consumers now have such a wide choice of competitive products (and services) that the concept of service quality is as applicable to product consumption as it is to service consumption. Pels (1999:19) suggests that exchange situations can be of a transaction, relationship or hybrid type. Such exchange situations can clearly be related to the consumption of both products and services, so that the relationship situation can also apply to the consumption of products. Johns (2000:959) also suggests that "customers do not buy goods or services in the traditional sense. They buy an offering and the value [may] consist of many components, some of them being activities (service) and some being things (goods). As a consequence, the traditional division between goods and services is long outdated".

In conclusion the authors are of the opinion that, although the validity of the cause-effect relationship inherent in the serviceprofit chain model may be debated, there is little doubt that from a purely pragmatic perspective (1) a business can only be profitable if it has a sufficiently large customer base, and (2) getting and retaining this customer base is for most businesses at least in part a function of the contribution employees make in terms of quality, service levels, and efficiency and effectiveness.

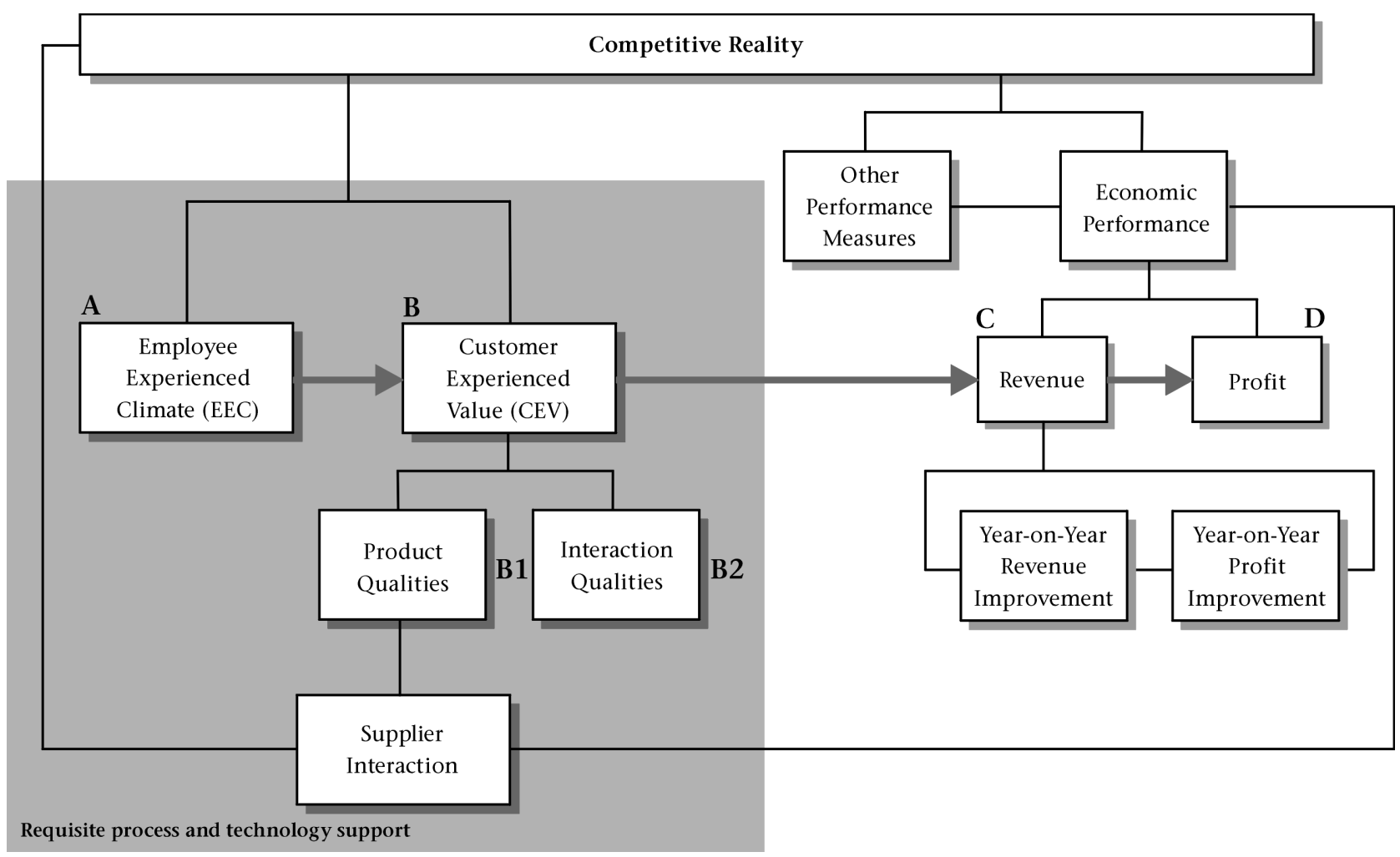

Figure 2: A model of employee- and customer-based sustainable performance 


\section{AN EXPANDED SERVICE-PROFIT CHAIN MODEL}

Against the background discussed above, the operational research model for the study being reported on can now be presented.

\section{Conceptual Model}

Given the content of the preceding sections, it is possible to conceptualise the service-profit chain diagrammatically within the broader parameters of macro trends and organisational performance and competitive reality. The extended model follows below.

The essential features of this diagram may be described as follows:

- The competitive position that an organisation achieves and is able to sustain is determined in the first instance by its entire competitive reality. One of the consequences of this competitive reality is that the expectations of key stakeholders of the organisation will also change.

- These changed expectations give rise to the necessity to measure organisational performance not only in terms of financial measures, but also in terms of other measures of performance (whether a triple bottom-line, balanced scorecard or other approach is adopted is possibly not that important, and as has been pointed out already will at least in part be based on the particular belief systems in place within the organisation).

- Economic and other measures of performance are not mutually exclusive nor independent of one another.

- Economic measures should include revenue (marked C in the diagram), profit (marked D in the diagram), and an improvement in both these metrics to ensure that sustainable longer-term growth is possible.

- Delivery of excellence in terms of the economic measures (i.e. meeting or exceeding financial performance targets) will require: - customer-experienced value (CEV) or external service quality (marked B in the diagram), which is dependent upon both product and interaction qualities (marked B1 and B2 respectively in the diagram) - keeping in mind that for product qualities the organisation is at least in part dependent on suppliers;

$\circ$ a positive employee-experienced climate (EEC), which is primarily dependent upon internal service quality (marked A in the diagram); and

o the requisite support through processes, technologies and systems.

\section{Research Model}

In terms of the focus of this particular research, the key aspects of the model outlined above are extracted as per the following diagram.

As can be seen from this diagram, essentially two sets of interactions are to be investigated, i.e.:

- Employee-experienced Climate and Customer-experienced Value (the relationship between variables A and B); and

- Customer-experienced Value and Economic Performance (the relationship between variables $B$ and $C$ and $D$ respectively).

\section{METHODOLOGY AND RESULTS}

The research process consisted of a number of phases, namely:

- Construction of the two questionnaires;

- Execution of the data collection phase;
- Data capture and validation; and

- Statistical analyses.

The sample consisted of:

- 94 stores for whom revenue and profit contribution was provided for two consecutive financial years; with

- a combined total of 1206 employees who completed the employee climate questionnaire; and

- a combined total of 2244 customers who completed the customer value questionnaire.

\section{Questionnaire Dimensions}

Through the use of item reliability and principal component analysis, the two questionnaires were found to assess the following dimensions.

TABLE 1

COMPONENT NAMES: EMPLOYEE QUESTIONNAIRE

\begin{tabular}{ll}
\hline Component Number & Component Name \\
\hline 1 & Management Style \\
2 & Teamwork \\
3 & Strategy Alignment \\
4 & General Satisfaction \\
5 & Recognition \\
6 & Values \\
7 & Participation \\
8 & Role Clarity \\
9 & Structure \\
10 & Trust \\
\hline
\end{tabular}

TABLE 2

COMPONENT NAMES: CUSTOMER QUESTIONNAIRE

\begin{tabular}{ll}
\hline Component Number & Component Name \\
\hline 1 & Interaction Value \\
2 & Product Value \\
\hline
\end{tabular}

Testing the Research Model

The following procedures were followed:

- For each employee, a total score per component was calculated as well as a total score for all items of the relevant questionnaire combined.

- The component and total scores were averaged per store.

- For each customer, a total score per component was calculated as well as a total score for all items of the relevant questionnaire combined.

- The component and total scores were averaged per store.

- For each store, sales revenue for the current financial year (year 2) was compared to budgeted revenue and coded either 1 (yes) or 0 (no), depending on whether budget had been exceeded (code 1 ) or not (code 0 ).

- For each store, sales revenue for the current financial year (year 2) was compared to sales revenue for the preceding year (year 1) and coded either 1 (yes) or 0 (no), depending on

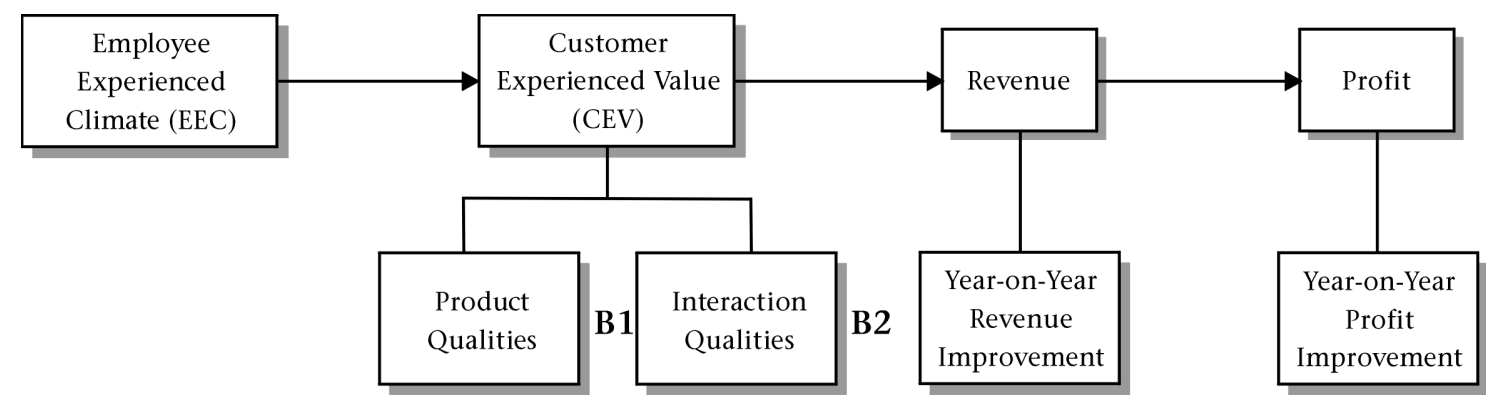


whether the year 2 figure exceeded the year 1 figure (code 1) or not (code 0).

- For each store, profit contribution for the current financial year (year 2) was compared to budgeted contribution and coded either 1 (yes) or 0 (no), depending on whether budget had been exceeded (code 1) or not (code 0 ).

- For each store, profit contribution for the current financial year (year 2) was compared to profit contribution for the preceding year (year 1) and coded either 1 (yes) or 0 (no), depending on whether the year 2 figure exceeded the year 1 figure (code 1) or not (code 0 ).

\section{Employee Climate and Customer Value}

The following hypothesis was formulated with regard to this aspect of the operational research model:

Stores ranked higher on customer satisfaction will also display higher average scores for employee climate.

In order to test this hypothesis, the following additional data manipulation was performed:

- Based on the total scores for both the customer and employee questionnaires respectively, stores were ranked from 1 to 94 (high to low), resulting in each store being given two rankings, one for each questionnaire's total score; and

- Based on these rankings, stores were grouped into three categories on each of the two rankings, these being labelled 1 for being in the top 30, 2 for being in the middle 34 , and 3 for being in the bottom 30 stores.

Using this method, it could now be determined whether the top 30 stores based on overall customer value had a higher average score for employee climate. The following table indicates that the stores with a higher customer value ranking (CEVROG : Customer Experienced Value Rank Order Grouping = 1) have higher mean scores for all the employee climate components as well as for the total employee climate score.

An analysis of variance further indicates that some of these differences between means are significant at the 0.005 level, as shown in the following table.
In order to further analyse the differences between the three sets of means, a post hoc comparison of means using the Tukey HSD test was conducted. The results of this analysis are reflected in the following table.

This table indicates that for stores ranked high (group 1) versus stores ranked low (group 3) on overall customer value, there are significant differences in the mean employee climate score on the following components:

- Total employee climate

- Management;

- Team Working;

- Participation;

- Role Clarity; and

- Structure.

Given that it has been indicated that stores ranked higher on customer value also display higher mean scores for overall employee climate as well as some of its components, these results can therefore be taken to provisionally prove the first hypothesis. To obtain full acceptance of this hypothesis, the relationship between the dimensions of customer value and employee climate was also investigated. The following table contains the correlations between these components, as well as their respective significances.

Clearly, of interest in this situation are the correlations between the two customer value and the ten employee climate dimensions. For the purposes of the following diagram, only correlations significant at least at the 0.010 level are used.

This diagram in Figure 4 illustrates that although some employee climate components overlap (management, role clarity, structure) in terms of being related to both customer value components, there are also employee climate components that relate only to the relationship aspect of customer value, these being Teamworking, General Satisfaction and Participation. Clearly, the relationship between employeeexperienced climate and customer-experienced value is more complex than is immediately apparent. Given all these findings, hypothesis one can however by accepted as proven.

TABLE 3

EMPLOYEE CLIMATE MEAN SCORES PER CUSTOMER VALUE GROUPING

\begin{tabular}{|c|c|c|c|c|c|c|c|c|c|c|c|c|}
\hline \multicolumn{13}{|c|}{ Case summaries } \\
\hline & CEVROG & EECTotal & Manage & Team & Strategy & General & Recognition & Values & Participation & Role & Structure & Trust \\
\hline \multirow[t]{2}{*}{1} & Mean & 182.9360 & 53.6160 & 18.7147 & 20.1593 & 21.2060 & 13.0450 & 12.1150 & 11.1823 & 17.5040 & 9.0907 & 6.3040 \\
\hline & $\begin{array}{l}\text { Std. } \\
\text { Deviation }\end{array}$ & 21.2625 & 8.2744 & 2.9233 & 3.2239 & 2.8478 & 2.3044 & 2.1796 & 2.1942 & 1.3836 & 1.3556 & .9804 \\
\hline \multirow[t]{2}{*}{2} & Mean & 177.1626 & 49.1124 & 17.4838 & 20.8418 & 20.8141 & 13.3715 & 12.2662 & 10.8356 & 17.1868 & 9.0756 & 6.1756 \\
\hline & $\begin{array}{l}\text { Std. } \\
\text { Deviation }\end{array}$ & 24.7163 & 9.6002 & 2.8151 & 3.2971 & 3.5487 & 1.8554 & 1.4408 & 1.8426 & 1.4349 & 1.4665 & 1.0796 \\
\hline \multirow[t]{2}{*}{3} & Mean & 162.7540 & 43.9497 & 16.6570 & 18.5143 & 19.2957 & 11.8097 & 12.1343 & 9.9850 & 16.3817 & 8.0990 & 5.9293 \\
\hline & $\begin{array}{l}\text { Std. } \\
\text { Deviation }\end{array}$ & 24.1698 & 11.9044 & 2.4715 & 3.1760 & 3.3709 & 2.0048 & 1.5804 & 1.5222 & 1.1825 & 1.2260 & 1.0072 \\
\hline \multirow[t]{2}{*}{ Total } & Mean & 174.4067 & 48.9020 & 17.6128 & 19.8812 & 20.4546 & 12.7688 & 12.1759 & 10.6748 & 17.0311 & 8.7687 & 6.1380 \\
\hline & Std. Deviation & 24.6972 & 10.6461 & 2.8415 & 3.3479 & 3.3472 & 2.1413 & 1.7352 & 1.9169 & 1.4073 & 1.4204 & 1.0262 \\
\hline
\end{tabular}

ES per customer value grouping case summaries

Case summaries

\begin{tabular}{|c|c|c|c|c|c|c|c|c|c|c|c|c|}
\hline & CEVROG & EECTotal & Manage & Team & Strategy & General & Recognition & Values & Participation & Role & Structure & Trust \\
\hline 1 & $\begin{array}{l}\text { Mean } \\
\text { Std. } \\
\text { Deviation }\end{array}$ & $\begin{array}{c}\mathbf{1 8 2 . 9 3 6 0} \\
21.2625\end{array}$ & $\begin{array}{c}53.6160 \\
8.2744\end{array}$ & $\begin{array}{l}18.7147 \\
2.9233\end{array}$ & $\begin{array}{c}20.1593 \\
3.2239\end{array}$ & $\begin{array}{c}21.2060 \\
2.8478\end{array}$ & $\begin{array}{l}13.0450 \\
2.3044\end{array}$ & $\begin{array}{c}12.1150 \\
2.1796\end{array}$ & $\begin{array}{l}11.1823 \\
2.1942\end{array}$ & $\begin{array}{c}17.5040 \\
1.3836\end{array}$ & $\begin{array}{l}9.0907 \\
1.3556\end{array}$ & $\begin{array}{c}6.3040 \\
.9804\end{array}$ \\
\hline 2 & $\begin{array}{l}\text { Mean } \\
\text { Std. } \\
\text { Deviation }\end{array}$ & $\begin{array}{c}177.1626 \\
24.7163\end{array}$ & $\begin{array}{l}49.1124 \\
9.6002\end{array}$ & $\begin{array}{c}17.4838 \\
2.8151\end{array}$ & $\begin{array}{c}20.8418 \\
3.2971\end{array}$ & $\begin{array}{c}20.8141 \\
3.5487\end{array}$ & $\begin{array}{c}13.3715 \\
1.8554\end{array}$ & $\begin{array}{c}12.2662 \\
1.4408\end{array}$ & $\begin{array}{c}10.8356 \\
1.8426\end{array}$ & $\begin{array}{c}17.1868 \\
1.4349\end{array}$ & $\begin{array}{l}9.0756 \\
1.4665\end{array}$ & $\begin{array}{l}6.1756 \\
1.0796\end{array}$ \\
\hline 3 & $\begin{array}{l}\text { Mean } \\
\text { Std. } \\
\text { Deviation }\end{array}$ & $\begin{array}{c}162.7540 \\
24.1698\end{array}$ & $\begin{array}{l}43.9497 \\
11.9044\end{array}$ & $\begin{array}{c}16.6570 \\
2.4715\end{array}$ & $\begin{array}{c}18.5143 \\
3.1760\end{array}$ & $\begin{array}{c}19.2957 \\
3.3709\end{array}$ & $\begin{array}{l}11.8097 \\
2.0048\end{array}$ & $\begin{array}{l}12.1343 \\
1.5804\end{array}$ & $\begin{array}{l}9.9850 \\
1.5222\end{array}$ & $\begin{array}{c}16.3817 \\
1.1825\end{array}$ & $\begin{array}{l}8.0990 \\
1.2260\end{array}$ & $\begin{array}{l}5.9293 \\
1.0072\end{array}$ \\
\hline Total & $\begin{array}{l}\text { Mean } \\
\text { Std. Deviation }\end{array}$ & $\begin{array}{c}174.4067 \\
24.6972\end{array}$ & $\begin{array}{l}48.9020 \\
10.6461\end{array}$ & $\begin{array}{c}17.6128 \\
2.8415\end{array}$ & $\begin{array}{c}19.8812 \\
3.3479\end{array}$ & $\begin{array}{c}20.4546 \\
3.3472\end{array}$ & $\begin{array}{c}12.7688 \\
2.1413\end{array}$ & $\begin{array}{c}12.1759 \\
1.7352\end{array}$ & $\begin{array}{c}10.6748 \\
1.9169\end{array}$ & $\begin{array}{c}17.0311 \\
1.4073\end{array}$ & $\begin{array}{l}8.7687 \\
1.4204\end{array}$ & $\begin{array}{l}6.1380 \\
1.0262\end{array}$ \\
\hline
\end{tabular}


TABLE 4

Anova EMPloyee Means

\begin{tabular}{|c|c|c|c|c|c|c|}
\hline & & $\begin{array}{l}\text { Sum } \\
\text { Squar }\end{array}$ & df & Mean & $\mathrm{F}$ & Sig. \\
\hline $\begin{array}{l}\text { EECTOT } \\
\text { Between }\end{array}$ & $\begin{array}{c}\text { Within } \\
\text { Total }\end{array}$ & $\begin{array}{r}6514.27 \\
50211.40 \\
56725.56\end{array}$ & $\begin{array}{r}2 \\
91 \\
93\end{array}$ & $\begin{array}{r}3257.13 \\
551.77\end{array}$ & 5.90 & .00 \\
\hline $\begin{array}{l}\text { Manage } \\
\text { Between }\end{array}$ & $\begin{array}{c}\text { Within } \\
\text { Total }\end{array}$ & $\begin{array}{r}1403.9 \\
9136.61 \\
10540.53\end{array}$ & $\begin{array}{r}2 \\
91 \\
93\end{array}$ & $\begin{array}{r}2701.96 \\
100.40\end{array}$ & 6.99 & .00 \\
\hline $\begin{array}{l}\text { Teamwork } \\
\text { Between }\end{array}$ & $\begin{array}{l}\text { Within } \\
\text { Total }\end{array}$ & $\begin{array}{r}64.39 \\
686.49 \\
750.88\end{array}$ & $\begin{array}{r}2 \\
91 \\
93\end{array}$ & $\begin{array}{r}32.19 \\
7.54\end{array}$ & 4.26 & .01 \\
\hline $\begin{array}{l}\text { Strategy } \\
\text { Between }\end{array}$ & $\begin{array}{l}\text { Within } \\
\text { Total }\end{array}$ & $\begin{array}{r}89.74 \\
952.66 \\
1042.41\end{array}$ & $\begin{array}{r}2 \\
91 \\
93\end{array}$ & $\begin{array}{l}44.87 \\
10.46\end{array}$ & 4.28 & .01 \\
\hline $\begin{array}{l}\text { General } \\
\text { Between }\end{array}$ & $\begin{array}{l}\text { Within } \\
\text { Total }\end{array}$ & $\begin{array}{r}61.62 \\
980.30 \\
1041.93\end{array}$ & $\begin{array}{r}2 \\
91 \\
93\end{array}$ & $\begin{array}{l}30.81 \\
10.77\end{array}$ & 2.86 & .06 \\
\hline $\begin{array}{l}\text { Recognition } \\
\text { Between }\end{array}$ & $\begin{array}{l}\text { Within } \\
\text { Total }\end{array}$ & $\begin{array}{r}42.23 \\
384.16 \\
426.40\end{array}$ & $\begin{array}{r}2 \\
91 \\
93\end{array}$ & $\begin{array}{r}21.11 \\
4.22\end{array}$ & 5.00 & .00 \\
\hline $\begin{array}{l}\text { Values } \\
\text { Between }\end{array}$ & $\begin{array}{l}\text { Within } \\
\text { Total }\end{array}$ & $\begin{array}{r}.44 \\
278.70 \\
279.14\end{array}$ & $\begin{array}{r}2 \\
91 \\
93\end{array}$ & $\begin{array}{r}.22 \\
3.06\end{array}$ & .07 & .93 \\
\hline $\begin{array}{l}\text { Participation } \\
\text { Between }\end{array}$ & $\begin{array}{l}\text { Within } \\
\text { Total }\end{array}$ & $\begin{array}{r}22.88 \\
164.01 \\
184.19\end{array}$ & $\begin{array}{r}2 \\
91 \\
93\end{array}$ & $\begin{array}{r}11.44 \\
3.50\end{array}$ & 3.26 & .04 \\
\hline $\begin{array}{l}\text { Role } \\
\text { Between }\end{array}$ & $\begin{array}{l}\text { Within } \\
\text { Total }\end{array}$ & $\begin{array}{r}20.18 \\
164.01 \\
184.19\end{array}$ & $\begin{array}{r}2 \\
91 \\
93\end{array}$ & $\begin{array}{r}10.09 \\
1.80\end{array}$ & 5.60 & .00 \\
\hline $\begin{array}{l}\text { Structure } \\
\text { Between }\end{array}$ & $\begin{array}{l}\text { Within } \\
\text { Total }\end{array}$ & $\begin{array}{r}19.76 \\
167.85 \\
187.62\end{array}$ & $\begin{array}{r}2 \\
91 \\
93\end{array}$ & $\begin{array}{l}9.88 \\
1.84\end{array}$ & 5.35 & .00 \\
\hline $\begin{array}{l}\text { Trust } \\
\text { Between }\end{array}$ & $\begin{array}{r}\text { Within } \\
\text { Total }\end{array}$ & $\begin{array}{r}2.18 \\
95.76 \\
97.94\end{array}$ & $\begin{array}{r}2 \\
91 \\
93\end{array}$ & $\begin{array}{l}1.09 \\
1.05\end{array}$ & 1.03 & .35 \\
\hline
\end{tabular}

Customer Value and Financial Performance

The following hypotheses were formulated with regard to this aspect of the operational research model:

Stores ranked higher on sales revenue performance as compared

to budgeted performance will display higher average scores for customer satisfaction.

Stores ranked higher on sales revenue performance improvement from year 1 to year 2 will display higher average scores for customer satisfaction.

Stores ranked higher on sales profit contribution performance will display higher average scores for customer satisfaction.

Stores ranked higher on sales profit contribution performance improvement from year 1 to year 2 will display higher average scores for customer satisfaction.

In order to test these hypotheses the following additional data manipulation was performed:

- Based on the percentage deviation of actual sales revenue and actual profit contribution from budgeted sales revenue and budgeted profit contribution in year 1 , stores were ranked from high to low (this will indicate in relative terms the sales revenue performance of stores in year 1).

- Based on the percentage deviation of actual sales revenue and actual profit contribution in year 2 from actual sales revenue and actual profit contribution in year 1 , stores were ranked from high to low (this will indicate in relative terms the sales revenue and profit contribution performance improvement of stores in year 2 compared to year 1).

- Based on these rankings, stores were grouped into three categories on each of the rankings, these being a grouping of 1 for being in the top 30, a grouping of 3 for being in the bottom 30, and a grouping of 2 for being in the middle 34 stores.

Using this method, it could now be determined whether stores in grouping 1 (high performers) based on each of the revenue/profit contribution rankings had a higher average score for customer value than stores in grouping 3 (low performers).

The following two tables show that for both revenue and profit contributions, there is no statistically significant relationship between these measures of financial performance and customerexperienced value.

None of hypotheses 2 to 5 could be proven. This is further confirmed by the following table which indicates that there are no significant correlations between the rank order scores for Customer Experienced Value (CEV), Employee Experienced Climate (EEC) and any of the sales revenue or profit contribution rank order scores.

The results reported can best be summarised as per the diagram in figure 5.

Given that hypothesis 1 was proven, the diagram illustrates that overall employee climate, as well as some of its components, is related to customer-experienced value. The fact that hypotheses 2 through 5 could, however, not be proven is reflected in the greyed typing in the diagram. It is clear from the results that the postulated relationship between variables $\mathrm{A}$ and $\mathrm{B}$ in the diagram has been proven, but that the relationship between variables $B$ and $C$ and $D$ respectively has not been proven.

\section{RECOMMENDATIONS}

A number of recommendations can be made to further the understanding of the vital link between suppliers, organisations and their employees, and the customer, and the impact that this has on the sustainable performance of the organisation, including its ability to serve the interests of all its key and relevant stakeholders. These recommendations can be classified into three levels, i.e. issues external to the organisation, those internal to the organisation, and finally issues relating to the dynamic interplay between the variables.

\section{External Context}

In the first instance, the external context of the organisation should be understood in specific detail. Some of the issues to be clarified in future research include:

- A single quantitative (questionnaire) measure of customerexperienced value assumes that customers have similar expectations. It is therefore recommended that future research should factor in the influence of the geographical/ cultural/social/economic context of customers of the organisation. 
TABLE 5

POST HOC MEAN COMPARISON FOR EMPLOTEE CLIMATE

\begin{tabular}{|c|c|c|c|c|c|c|c|}
\hline \multicolumn{8}{|c|}{ Multiple Comparisons } \\
\hline \multirow[b]{3}{*}{ Dependent Variable } & \multirow[b]{3}{*}{ (I) CEVROG } & \multirow[b]{3}{*}{ (J) CEVROG } & \multicolumn{2}{|c|}{ Tukey HSD } & \multirow[b]{3}{*}{ Sig. } & \multirow{2}{*}{\multicolumn{2}{|c|}{ 95\% Confidence Interval }} \\
\hline & & & Mean & & & & \\
\hline & & & $(\mathrm{I}-\mathrm{J})$ & Std. Error & & Lower Bound & Upper Bound \\
\hline \multirow[t]{6}{*}{ EECTOTAL } & \multirow[t]{2}{*}{1} & 2 & 5.7734 & 5.8840 & .591 & -8.2462 & 19.7929 \\
\hline & & 3 & 20.1820 * & 6.0651 & .004 & 5.7310 & 34.6330 \\
\hline & \multirow[t]{2}{*}{2} & 1 & -5.7734 & 5.8840 & .591 & -19.7929 & 8.2462 \\
\hline & & 3 & 14.4086 * & 5.8840 & .043 & .3891 & 28.4282 \\
\hline & 3 & 1 & $-20.1820 *$ & 6.0651 & .004 & -34.6330 & -5.7310 \\
\hline & & 2 & -14.4086 * & 5.8840 & .043 & -28.4282 & -.3891 \\
\hline Management & 1 & 2 & 4.5036 & 2.5099 & .177 & -1.4767 & 10.4840 \\
\hline & & 3 & 9.6663 * & 2.5872 & .001 & 3.5020 & 15.8307 \\
\hline & 2 & 1 & -4.5036 & 2.5099 & .177 & -10.4840 & 1.4767 \\
\hline & & 3 & 5.1627 & 2.5099 & .105 & -.8176 & 11.1430 \\
\hline & 3 & 1 & -9.6663 * & 2.5872 & .001 & -15.8307 & -3.5020 \\
\hline & & 2 & -5.1627 & 2.5099 & .105 & -11.1430 & .8176 \\
\hline Teamworking & 1 & 2 & 1.2308 & .6880 & .179 & -.4084 & 2.8701 \\
\hline & & 3 & 2.0577 * & .7092 & .013 & .3680 & 3.7474 \\
\hline & 2 & 1 & -1.2308 & .6880 & .179 & -2.8701 & .4084 \\
\hline & & 3 & .8268 & .6880 & .455 & -.8124 & 2.4661 \\
\hline & 3 & 1 & -2.0577 * & .7092 & .013 & -3.7474 & -.3680 \\
\hline & & 2 & -.8268 & .6880 & .455 & -2.4661 & .8124 \\
\hline Strategy & 1 & 2 & -.6824 & .8105 & .678 & -2.6135 & 1.2487 \\
\hline & & 3 & 1.6450 & .8354 & .126 & -.3455 & 3.6355 \\
\hline & 2 & 1 & .6824 & .8105 & .678 & -1.2487 & 2.6135 \\
\hline & & 3 & 2.3274 * & .8105 & .014 & .3963 & 4.2585 \\
\hline & 3 & 1 & -1.6450 & .8354 & .126 & -3.6355 & .3455 \\
\hline & & 2 & -2.3274 * & .8105 & .014 & -4.2585 & -.3963 \\
\hline General & 1 & 2 & .3919 & .8221 & .882 & -1.5670 & 2.3508 \\
\hline & & 3 & 1.9103 & .8474 & .068 & -.1089 & 3.9295 \\
\hline & 2 & 1 & -.3919 & .8221 & .882 & -2.3508 & 1.5670 \\
\hline & & 3 & 1.5185 & .8221 & .160 & -.4405 & 3.4774 \\
\hline & 3 & 1 & -1.9103 & .8474 & .068 & -3.9295 & .1089 \\
\hline & & 2 & -1.5185 & .8221 & .160 & -3.4774 & .4405 \\
\hline Recognition & 1 & 2 & -.3265 & .5147 & .802 & -1.5528 & .8998 \\
\hline & & 3 & 1.2353 & .5305 & .057 & $-2.8696 \mathrm{E}-02$ & 2.4994 \\
\hline & 2 & 1 & .3265 & .5147 & .802 & -.89998 & 1.5528 \\
\hline & & 3 & 1.5618 * & .5147 & .009 & .3355 & 2.7881 \\
\hline & 3 & 1 & -1.2353 & .5305 & .057 & -2.4994 & $2.870 \mathrm{E}-02$ \\
\hline & & 2 & -1.5618 * & .5147 & .009 & -2.7881 & -.3355 \\
\hline Values & 1 & 2 & -.1512 & .4384 & .937 & -1.1957 & .8933 \\
\hline & & 3 & $-1.9333 \mathrm{E}-02$ & .4519 & .999 & -1.0960 & 1.0573 \\
\hline & 2 & 1 & .1512 & .4384 & .937 & -.8933 & 1.1957 \\
\hline & & 3 & .1318 & .7384 & .951 & -.9126 & 1.1763 \\
\hline & 3 & 1 & $1.933 \mathrm{E}-02$ & .4519 & .999 & -1.0573 & 1.0960 \\
\hline & & 2 & -.1318 & .4384 & .951 & -1.1763 & .9126 \\
\hline Participation & 1 & 2 & .3467 & .4689 & .741 & -.7705 & 1.4640 \\
\hline 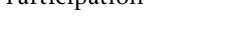 & & 3 & 1.1973 * & .4833 & .040 & $4.574 \mathrm{E}-02$ & 2.3489 \\
\hline & 2 & 1 & -.3467 & .4689 & .741 & -1.4640 & .7705 \\
\hline & & 3 & .8506 & .4689 & .171 & -.2666 & 1.9678 \\
\hline & 3 & 1 & -1.1973 * & .4833 & .040 & -2.3489 & $-4.5744 \mathrm{E}-02$ \\
\hline & & 2 & -.8506 & .4689 & .171 & -1.9678 & .2666 \\
\hline Role & 1 & 2 & .3172 & .3363 & .614 & -.4840 & 1.1185 \\
\hline Nore & & 3 & 1.1223 * & .3466 & .005 & .2964 & 1.9482 \\
\hline & 2 & 1 & -3172 & .3363 & .614 & -1.1185 & .4840 \\
\hline & & 3 & .8051 * & .3363 & .049 & $3.843 \mathrm{E}-03$ & 1.6064 \\
\hline & 3 & 1 & -1.1223 & .3466 & .005 & -1.9482 & -.2964 \\
\hline & & 2 & -.8051 * & .3363 & .049 & -1.6064 & $-3.8428 \mathrm{E}-03$ \\
\hline Structure & 1 & 2 & $1.508 \mathrm{E}-02$ & .3402 & .999 & -.795 & .8257 \\
\hline & & 3 & .9917 * & .3507 & .016 & .1561 & 1.8272 \\
\hline & 2 & 1 & $-1.5078 \mathrm{E}-02$ & .3402 & .999 & -.8257 & .7955 \\
\hline & & 3 & .9766 * & .3402 & .014 & .1660 & 1.7872 \\
\hline & 3 & 1 & -.9917 * & .3507 & .016 & -1.8272 & -.1561 \\
\hline & & 2 & -.9766 * & .3402 & .014 & -1.7872 & -.1660 \\
\hline Trust & 1 & 2 & .1284 & .2570 & .872 & -.4838 & .7407 \\
\hline 1rust & & 3 & .3747 & .2649 & .338 & -.2564 & 1.0058 \\
\hline & 2 & 1 & -.1284 & .2570 & .872 & -.7407 & .4383 \\
\hline & & 3 & .2463 & .2570 & .605 & -.3660 & .8585 \\
\hline & 3 & 1 & -.3747 & .2649 & .338 & -1.0058 & .2564 \\
\hline & & 2 & -.2463 & .2570 & .605 & -.8585 & .3660 \\
\hline
\end{tabular}

* The mean difference is significant at the .05 level. 
TABLE 6

EMPLOYEE AND CUSTOMER COMPONENT CORRELATIONS

\begin{tabular}{|c|c|c|c|c|c|c|c|c|c|c|c|c|c|}
\hline \multicolumn{14}{|c|}{ Correlations } \\
\hline & & $\begin{array}{l}\text { Inter- } \\
\text { action }\end{array}$ & Product & $\begin{array}{l}\text { Manage- } \\
\text { ment }\end{array}$ & $\begin{array}{c}\text { Team- } \\
\text { working }\end{array}$ & Strategy & General & $\begin{array}{l}\text { Recog- } \\
\text { nition }\end{array}$ & Values & $\begin{array}{l}\text { Partici- } \\
\text { pation }\end{array}$ & Role & Structure & Trust \\
\hline \multirow{3}{*}{$\begin{array}{l}\text { Inter- } \\
\text { action }\end{array}$} & Pearson Correlation & 1.000 & $.787 * *$ & .369 ** & $.329 * *$ & .180 & $.241 *$ & .198 & .034 & $.284 * *$ & $.342 * *$ & $.340 * *$ & .187 \\
\hline & Sig. (2-tailed) & & .000 & .000 & .001 & .083 & .019 & .056 & .742 & .006 & .001 & .001 & .071 \\
\hline & $\mathrm{N}$ & 94 & 94 & 94 & 94 & 94 & 94 & 94 & 94 & 94 & 94 & 94 & 94 \\
\hline \multirow[t]{3}{*}{ Product } & Pearson Correlation & $.787 * *$ & 1.000 & $.296 * *$ & $.246 *$ & .192 & $.221 *$ & $.266 * *$ & .038 & .186 & $.277 * *$ & $.220 *$ & .057 \\
\hline & Sig. (2-tailed) & .000 & & .004 & .017 & .064 & .033 & .009 & .718 & .072 & .007 & .033 & .583 \\
\hline & $\mathrm{N}$ & 94 & 94 & 94 & 94 & 94 & 94 & 94 & 94 & 94 & 94 & 94 & 94 \\
\hline \multirow{3}{*}{$\begin{array}{l}\text { Manage- } \\
\text { ment }\end{array}$} & Pearson Correlation & $.369 * *$ & $.296 * *$ & 1.000 & $.626 * *$ & $.651 * *$ & $.692 * *$ & $.643 * *$ & $.344 * *$ & $.741 * *$ & $.476 * *$ & $.560 * *$ & $.609 * *$ \\
\hline & Sig. (2-tailed) & .000 & .004 & & .000 & .000 & .000 & .000 & .001 & .000 & .000 & .000 & .000 \\
\hline & $\mathrm{N}$ & 94 & 94 & 94 & 94 & 94 & 94 & 94 & 94 & 94 & 94 & 94 & 94 \\
\hline \multirow{3}{*}{$\begin{array}{l}\text { Team- } \\
\text { working }\end{array}$} & Pearson Correlation & $.329 * *$ & $.246 *$ & $.626^{* *}$ & 1.000 & $.628 * *$ & $.746 * *$ & $.497 * *$ & $.483 * *$ & $.706 * *$ & $.700 * *$ & $.547 * *$ & $.707 * *$ \\
\hline & Sig. (2-tailed) & .001 & .017 & .000 & & .000 & .000 & .000 & .000 & .000 & .000 & .000 & .000 \\
\hline & $\mathrm{N}$ & 94 & 94 & 94 & 94 & 94 & 94 & 94 & 94 & 94 & 94 & 94 & 94 \\
\hline \multirow[t]{3}{*}{ Strategy } & Pearson Correlation & .180 & .192 & $.651 * *$ & $.628 * *$ & 1.000 & $.760 * *$ & $.693 * *$ & $.616 * *$ & $.554 * *$ & $.611 * *$ & $.584 * *$ & $.612 * *$ \\
\hline & Sig. (2-tailed) & .083 & .064 & .000 & .000 & & .000 & .000 & .000 & .000 & .000 & .000 & .000 \\
\hline & $\mathrm{N}$ & 94 & 94 & 94 & 94 & 94 & 94 & 94 & 94 & 94 & 94 & 94 & 94 \\
\hline \multirow[t]{3}{*}{ General } & Pearson Correlation & $.241 *$ & $.221 *$ & $.692 * *$ & $.746 * *$ & $.760 * *$ & 1.000 & $.721 * *$ & $.695 * *$ & $.697 * *$ & $.542 * *$ & $.608 * *$ & $.673 * *$ \\
\hline & Sig. (2-tailed) & .019 & .033 & .000 & .000 & .000 & & .000 & .000 & .000 & .000 & .000 & .000 \\
\hline & $\mathrm{N}$ & 94 & 94 & 94 & 94 & 94 & 94 & 94 & 94 & 94 & 94 & 94 & 94 \\
\hline \multirow{3}{*}{$\begin{array}{l}\text { Recog- } \\
\text { nition }\end{array}$} & Pearson Correlation & .198 & $.266 * *$ & $.643 * *$ & $.497 * *$ & $.693 * *$ & $.721 * *$ & 1.000 & $.531 * *$ & $.533 * *$ & $.502 * *$ & $.537 * *$ & $.501 * *$ \\
\hline & Sig. (2-tailed) & 0.56 & .009 & .000 & .000 & .000 & .000 & & .000 & .000 & .000 & .000 & .000 \\
\hline & $\mathrm{N}^{\circ}$ & 94 & 94 & 94 & 94 & 94 & 94 & 94 & 94 & 94 & 94 & 94 & 94 \\
\hline \multirow[t]{3}{*}{ Values } & Pearson Correlation & .034 & .038 & $.344^{* *}$ & $.483 * *$ & $.616 * *$ & $.695 * *$ & $.531 * *$ & 1.000 & $.482 * *$ & $.526 * *$ & $.463 * *$ & $.435 * *$ \\
\hline & Sig. (2-tailed) & .742 & .718 & .001 & .000 & .000 & .000 & .000 & & .000 & .000 & .000 & .000 \\
\hline & $\mathrm{N}$ & 94 & 94 & 94 & 94 & 94 & 94 & 94 & 94 & 94 & 94 & 94 & 94 \\
\hline \multirow{3}{*}{$\begin{array}{l}\text { Partici- } \\
\text { pation }\end{array}$} & Pearson Correlation & $.284 * *$ & .186 & $.741 * *$ & $.706 * *$ & $.554 * *$ & $.697 * *$ & $.533 * *$ & $.481 * *$ & 1.000 & $.608 * *$ & $.605 * *$ & $.633 * *$ \\
\hline & Sig. (2-tailed) & .006 & .072 & .000 & .000 & .000 & .000 & .000 & .000 & & .000 & .000 & .000 \\
\hline & $\mathrm{N}$ & 94 & 94 & 94 & 94 & 94 & 94 & 94 & 94 & 94 & 94 & 94 & 94 \\
\hline \multirow[t]{3}{*}{ Role } & Pearson Correlation & $.342 * *$ & $.277^{* *}$ & $.476^{* *}$ & $.700 * *$ & $.611 * *$ & $.542 * *$ & $.502 * *$ & $.526 * *$ & $.608 * *$ & 1.000 & $.590 * *$ & $.583 * *$ \\
\hline & Sig. (2-tailed) & .001 & .007 & .000 & .000 & .000 & .000 & .000 & .000 & .000 & & .000 & .000 \\
\hline & $\mathrm{N}^{\circ}$ & 94 & 94 & 94 & 94 & 94 & 94 & 94 & 94 & 94 & 94 & 94 & 94 \\
\hline \multirow{3}{*}{$\begin{array}{l}\text { Struc- } \\
\text { ture }\end{array}$} & Pearson Correlation & $.340 * *$ & $.220 *$ & $.560^{* *}$ & $.547 * *$ & $.584 * *$ & $.608 * *$ & $.537 * *$ & $.463 * *$ & $.605 * *$ & $.590 * *$ & 1.000 & $.580 * *$ \\
\hline & Sig. (2-tailed) & .001 & .033 & .000 & .000 & .000 & .000 & .000 & .000 & .000 & .000 & & .000 \\
\hline & $\mathrm{N}^{\circ}$ & 94 & 94 & 94 & 94 & 94 & 94 & 94 & 94 & 94 & 94 & 94 & 94 \\
\hline \multirow[t]{3}{*}{ Trust } & Pearson Correlation & .187 & .057 & $.609 * *$ & $.707 * *$ & $.612 * *$ & $.673 * *$ & $.501 * *$ & $.435 * *$ & $.633 * *$ & $.583 * *$ & $.580 * *$ & 1.000 \\
\hline & Sig. (2-tailed) & .071 & .583 & .000 & .000 & .000 & .000 & .000 & .000 & .000 & .000 & .000 & \\
\hline & $\mathrm{N}$ & 94 & 94 & 94 & 94 & 94 & 94 & 94 & 94 & 94 & 94 & 94 & 94 \\
\hline
\end{tabular}

* * Correlation is significant at the 0.01 level (2-tailed).

* Correlation is significant at the 0.05 level (2-tailed).

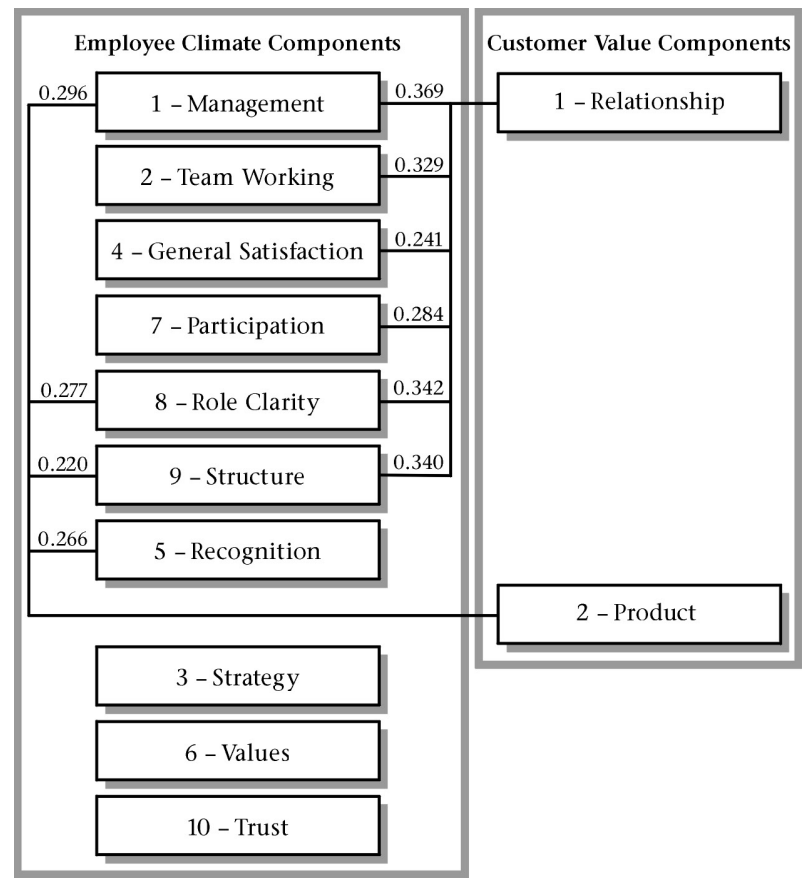

Figure 4: Employee climate and customer value component relationships
TABLE 7

Post HOC COMParison: Customer VAlue MeAN SCORES PeR SALES REVENUE IMPROVEMENT GROUPING ${ }^{3}$

\begin{tabular}{|c|c|c|c|c|c|c|c|}
\hline \multicolumn{8}{|c|}{ Multiple Comparisons } \\
\hline \multicolumn{8}{|l|}{ Tukey HSD } \\
\hline \multirow{2}{*}{$\begin{array}{l}\text { Dependent } \\
\text { Variable }\end{array}$} & \multirow{2}{*}{$\begin{array}{c}\text { (I) } \\
\text { RY2Over } \\
\text { Y1ROG }\end{array}$} & \multirow{2}{*}{$\begin{array}{c}\text { (J) } \\
\text { RY2Over } \\
\text { Y1ROG }\end{array}$} & \multirow{2}{*}{$\begin{array}{c}\text { Mean } \\
\text { Difference } \\
(\mathrm{I}-\mathrm{J})\end{array}$} & \multirow{2}{*}{$\begin{array}{l}\text { Std. } \\
\text { Error }\end{array}$} & \multirow[t]{2}{*}{ Sig. } & \multicolumn{2}{|c|}{$95 \%$ Confidence } \\
\hline & & & & & & $\begin{array}{l}\text { Lower } \\
\text { Bound }\end{array}$ & $\begin{array}{l}\text { Upper } \\
\text { Bound }\end{array}$ \\
\hline \multirow[t]{7}{*}{ Relationship } & 1 & 2 & -.5458 & .8845 & .811 & -.26532 & 1.5615 \\
\hline & & 3 & -1.3738 & .9257 & .303 & -3.5794 & .8319 \\
\hline & 2 & 1 & .5458 & .8845 & .811 & -1.5615 & 2.6532 \\
\hline & & 3 & -.8280 & .8926 & .624 & -2.9548 & 1.2989 \\
\hline & 3 & 1 & 1.3738 & .9257 & .303 & -.8319 & 3.5794 \\
\hline & & 2 & .8280 & .8926 & .624 & -1.2989 & 2.9548 \\
\hline & 1 & 2 & -.3085 & .3256 & .612 & -1.0842 & .4672 \\
\hline \multirow[t]{6}{*}{ Product } & & 3 & -.2717 & .3407 & .706 & -1.0836 & .5402 \\
\hline & & 3 & -.2717 & .3407 & .706 & -1.0836 & .5402 \\
\hline & 2 & 1 & .3085 & .3256 & .612 & -.4672 & 1.0842 \\
\hline & & 3 & $3.680 \mathrm{E}-02$ & .3286 & .993 & -.7461 & .8197 \\
\hline & 3 & 1 & .2717 & .3407 & .706 & -.5402 & 1.0836 \\
\hline & & $2-$ & $-3.6798 \mathrm{E}-02$ & .3286 & .993 & -.8197 & .7461 \\
\hline \multirow{6}{*}{ CEVTOTAL4 } & 1 & 2 & -.8391 & 1.1566 & .749 & -3.5950 & 1.9168 \\
\hline & & 3 & -1.6461 & 1.2106 & .366 & -4.5306 & 1.2383 \\
\hline & 2 & 1 & .8391 & 1.1566 & .749 & -1.9168 & 3.5950 \\
\hline & & 3 & -.8071 & 1.1673 & .769 & -3.5884 & 1.9743 \\
\hline & 3 & 1 & 1.6461 & 1.2106 & .366 & -1.2383 & 4.5306 \\
\hline & & 2 & .8071 & 1.1673 & .769 & -1.9743 & 3.5884 \\
\hline
\end{tabular}

3RY2OverY1ROG $=$ Rank order grouping for Revenue Year 2 compared to Year 1 ${ }^{4} \mathrm{CEVTOTAL}=$ Overall Customer Experienced Value score 
TABLE 8

Post HOC COMParison: CuSTOMER VAlue MEAN SCORES PER PROFIT CONTRIBUTION GROUPING ${ }^{5}$

Multiple Comparisons

\begin{tabular}{|c|c|c|c|c|c|c|c|}
\hline \multicolumn{8}{|l|}{ Tukey HSD } \\
\hline \multirow{2}{*}{$\begin{array}{l}\text { Dependent } \\
\text { Variable }\end{array}$} & \multirow{2}{*}{$\begin{array}{c}\text { (I) } \\
\text { PY2Over } \\
\text { Y1BROG }\end{array}$} & \multirow{2}{*}{$\begin{array}{c}(\mathrm{J}) \\
\text { PY2Over } \\
\text { Y1BROG }\end{array}$} & \multirow{2}{*}{$\begin{array}{c}\text { Mean } \\
\text { Difference } \\
(\mathrm{I}-\mathrm{J})\end{array}$} & \multirow{2}{*}{$\begin{array}{l}\text { Std. } \\
\text { Error }\end{array}$} & \multirow[t]{2}{*}{ Sig. } & \multicolumn{2}{|c|}{ 95\% Confidence } \\
\hline & & & & & & $\begin{array}{l}\text { Lower } \\
\text { Bound }\end{array}$ & $\begin{array}{l}\text { Upper } \\
\text { Bound }\end{array}$ \\
\hline \multirow[t]{6}{*}{ Relationship } & 1 & 2 & -.6881 & .8923 & .722 & -2.8142 & 1.4380 \\
\hline & & 3 & -.3917 & .9339 & .908 & -2.6170 & 1.8336 \\
\hline & 2 & 1 & .6881 & .8923 & .722 & -1.4380 & 2.8142 \\
\hline & & 3 & .2964 & .9006 & .942 & -1.8493 & 2.4421 \\
\hline & 3 & 1 & .3917 & .9339 & .908 & -1.8336 & 2.6170 \\
\hline & & 2 & -.2964 & .9006 & .942 & -2.4421 & 1.8493 \\
\hline \multirow[t]{6}{*}{ Product } & 1 & 2 & -3.977 & .3247 & .442 & -1.1713 & .3759 \\
\hline & & 3 & -.2634 & .3398 & .719 & -1.0731 & .5463 \\
\hline & 2 & 1 & .3977 & .3247 & .442 & -.3759 & 1.1713 \\
\hline & & 3 & .1343 & .3277 & .912 & -.6464 & .9151 \\
\hline & 3 & 1 & .2634 & .3398 & .719 & -.5463 & 1.0731 \\
\hline & & 2 & -.1343 & .3277 & .912 & -.9151 & .6464 \\
\hline \multirow[t]{6}{*}{ CEVTOTAL } & 1 & 2 & -1.0703 & 1.1629 & .629 & -3.8411 & 1.7005 \\
\hline & & 3 & -.6561 & 1.2172 & .852 & -3.5562 & 2.2440 \\
\hline & 2 & 1 & 1.0703 & 1.1629 & .629 & -1.7005 & 3.8411 \\
\hline & & 3 & .4142 & 1.1737 & .934 & -2.3822 & 3.2106 \\
\hline & 3 & 1 & .6561 & 1.2172 & .852 & -2.2440 & 3.5562 \\
\hline & & 2 & -.4142 & 1.1737 & .934 & -3.2106 & 2.3822 \\
\hline
\end{tabular}

5PY2AOverBROG $=$ Rank order grouping for Profit Year 2 Actual compared to Budget
TABLE 9

SPEARMAN CORRELATIONS: EMPLOYEE, CUSTOMER AND FINANCIAL RANKINGS ${ }^{6}$

\begin{tabular}{|c|c|c|c|c|c|c|c|c|}
\hline \multicolumn{9}{|c|}{ Correlations } \\
\hline & & & $\begin{array}{l}\text { CEV } \\
\text { Rank }\end{array}$ & $\begin{array}{l}\text { EEC } \\
\text { Rank }\end{array}$ & $\begin{array}{l}\text { RY2A } \\
\text { Over }\end{array}$ & $\begin{array}{l}\text { RY2 } \\
\text { OverY }\end{array}$ & $\begin{array}{l}\text { PY2A } \\
\text { Over }\end{array}$ & $\begin{array}{l}\text { PY2 } \\
\text { OverY }\end{array}$ \\
\hline \multirow{18}{*}{$\begin{array}{l}\text { Spearman's } \\
\text { rho }\end{array}$} & & Correlation & 1.000 & $.337 * *$ & -.091 & -.140 & -.047 & -.188 \\
\hline & CEV Rank & Sig. (2-tailed) & & .001 & .383 & .178 & .654 & .070 \\
\hline & Order & $\mathrm{N}$ & 94 & 94 & 94 & 94 & 94 & 94 \\
\hline & & Correlation & .337 & 1.000 & .023 & -.010 & .019 & -.005 \\
\hline & EEC Rank & Sig. (2-tailed) & .001 & & .828 & .922 & .859 & .963 \\
\hline & Order & $\mathrm{N}$ & 94 & 94 & 94 & 94 & 94 & 94 \\
\hline & & Correlation & -.091 & .023 & 1.000 & $.933 * *$ & * $.845^{* *}$ & * . $.808 * *$ \\
\hline & RY2AOver & Sig. (2-tailed) & .383 & .828 & & .000 & .000 & .000 \\
\hline & BRO & $\mathrm{N}$ & 94 & 94 & 94 & 94 & 94 & 94 \\
\hline & & Correlation & -.140 & -.010 & $.933 * *$ & * 1.000 & $.775^{* *}$ & $* \quad .866^{* *}$ \\
\hline & RY2OverY & Sig. (2-tailed) & .178 & .922 & .000 & & .000 & .000 \\
\hline & $1 \mathrm{RO}$ & $\mathrm{N}$ & 94 & 94 & 94 & 94 & 94 & 94 \\
\hline & & Correlation & -.047 & .019 & $.845^{* *}$ & * $.775^{* *}$ & * 1.000 & $.857^{* *}$ \\
\hline & PY2AOver & Sig. (2-tailed) & .654 & .859 & .000 & .000 & & .000 \\
\hline & Bro & $\mathrm{N}$ & 94 & 94 & 94 & 94 & 94 & 94 \\
\hline & & Correlation & -188 & -.005 & $.808^{* *}$ & * $.866^{* *}$ & * $.857^{\star *}$ & $* 1.000$ \\
\hline & PY2OverY & Sig. (2-tailed) & .070 & .963 & .000 & .000 & .000 & \\
\hline & $1 \mathrm{RO}$ & $\mathrm{N}$ & 94 & 94 & 94 & 94 & 94 & 94 \\
\hline
\end{tabular}

* Correlation is significant at the 01 level (2-tailed).

${ }_{5} \mathrm{RY} 2 \mathrm{AOverBROG}=$ Rank order grouping for Revenue Year 2 Actual compared to Budget

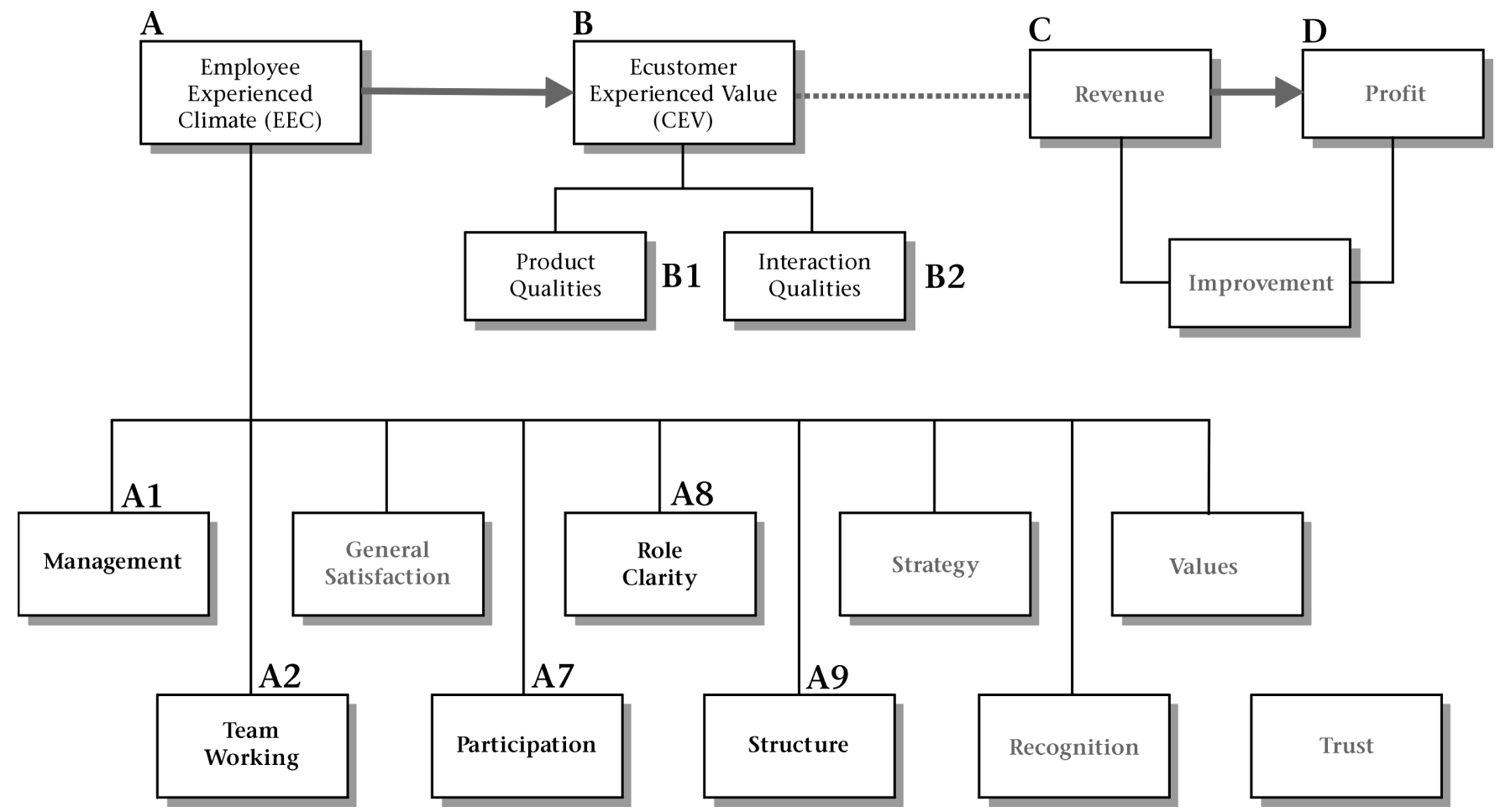

Figure 5: Summary of findings

- Single instruments claiming to be adequate to measure customer value across industries may be so general in nature, that they in fact add little value to the understanding of the uniqueness of an industry, the products/services it provides, and the key stakeholders it has to interact with given its own context. Instruments should be customised to reflect the unique dynamics of the industry within which the organisation operates.

Internal Context

The following recommendations can be made in terms of the organisation itself.
- Even if it was true that two organisations served the same customer base with similar (or even the same) products or services, each would position itself differently in terms of external communications, its internal business operating model and its culture. To assume that employee climate will have the same meaning or impact in both organisations may not be true. It is recommended that the specific drivers of employee climate within the organisation be identified and included in measures of employee-experienced climate.

- The capacity of the organisation to support a customer and market orientation should be included in such measurement instruments, as also indicated by Harris (2000). 
- The phase in the lifecycle of the organisation should be considered, as it is well known that organisations display very different behaviours towards external and internal stakeholders depending on what stage it finds itself in. Harris \& Ogbonna (2000) also refer to the impact of a marketoriented culture change on frontline employees.

\section{Relationship Dynamics}

The following recommendations can be made about the research process in terms of the relationships between various factors.

- Firstly, research of this kind almost by definition has to be longitudinal in nature. It is in all likelihood not so much the employee climate and customer value that are related to one another, but rather changes in employee climate over time, which will impact on customer-experienced value over time, which will impact on changes in financial measures over time.

- Secondly, financial measures as the only measures of performance should also be reconsidered. For example, in economic circumstances where all players in an industry are under pressure in terms of revenues and profits, they may still be delivering customer excellence through a positive workforce. In such cases, other measures of performance may be more accurate measures of the organisation's long-term sustainability. Perhaps the most telling comment on the service-profit chain comes from Silvestro \& Cross (2000:263), who suggest that "Heskett et al's service-profit chain is too simplistic a model to understand the drivers of business success, regardless of environmental and operational context".

- Finally, it is suggested that all research assessing perceptions of customers, employees and other key stakeholders include qualitative research to enrich and augment "the message of the numbers". Methodologies could include the themecentered interview as described by Schorn (2000), inductive category development (Mayring, 2000), and grounded theory (Samik-Ibrahim, 2000) who says that the strongest case for the use of the latter approach is in investigations of relatively uncharted water, or to gain a fresh perspective in a familiar situation.

\section{REFERENCES}

Allee, V. 2000. The value evolution. Addressing larger implications of an intellectual capital and intangibles perspective. Journal of Intellectual Capital. Vol. 1, No. 1, pp.17-32.

Bowman, J.S. \& Wittmer, D.L. 2000. The unfashionable Drucker : ethical and quality chic. Journal of Management History. Vol. 6, No. 1, pp.13-29.

Caruana, A. 1997. Corporate reputation: concept and measurement. Journal Of Product \& Brand Management. Vol. 6, No. 2, pp.109-118.

Caruana, A., Money, A.H. \& Berthon, P.R. 2000. Service quality and satisfaction - the moderating role of value. European Journal of Marketing. Vol. 34, No. 11/12, pp.1338-1352.

Cuthbert, P.F. 1996(a). Managing service quality in HE: is SERVQUAL the answer? Part 1. Managing Service Quality. Volume 6, Number 2: pp.11-16.

Cuthbert, P.F. 1996(b). Managing service quality in HE : is SERVQUAL the answer? Part 2. Managing Service Quality. Volume 6, Number 3: pp.31-35.

Dean, J.W. \& Bowen, D.E. 1994. Management theory and total quality: improving research and practice through theory development. Academy of Management Review. Vol. 19, No. 3, pp.392-418.

Devlin, J.F. 1998. Adding value to service offerings: the case of UK retail financial services. European Journal of Marketing. Vol. 32, No. 11/12, pp.1091-1109.

Durvasula, S., Lyons, S. and Mehta, S.C. 1999. Testing the SERVQUAL scale in the business-to-business sector: The case of ocean freight shipping service. The Journal of Services Marketing, Vol. 13, No. 2, pp.132-150.
Eccles, R. 1991. The performance measurement manifesto. Harvard Business Review. January-February, pp.131-137.

Elkington, J. 1997. Cannibals with Forks: the Triple Bottom Line of 21st Century Business. Capstone.

Fülöp, G., Hisrich, R.D \& Szegedi, K. 2000. Business ethics and social responsibility in transition economies. Journal of Management Development. Vol. 19, No. 1, pp. 5-31.

Grönroos, C. 1998. Marketing services: the case of a missing product. Journal of Business and Industrial Marketing. Vol. 13, No. $4 / 5$, pp.322-338.

Grönroos, C., Heinonen, F., Isoniemi, K. \& Lindholm, M. 2000. The NetOffer model : a case example from the virtual marketspace. Management Decision. Vol. 38, No. 4, pp.243252.

Handy, C. 1994. The Empty Raincoat. London: Hutchinson.

Harris, L.C. \& Ogbonna, E. 2000. The response of front-line employees to market-oriented culture change. European Journal of Marketing. Vol. 34, Issue 3/4, pp.2-23.

Harris, L.C. 1998. Cultural domination : the key to marketoriented culture? European Journal of Marketing. Vol. 32, No. 3/4, pp.354-373.

Heard, J. 2002. Fortune 500 list proves that customer is king. Sunday Times Business Times. April 14.

Heskett, J. L., Sasser, W.E. \& Schlesinger, L.A. 1997. The Serviceprofit chain. New York, The Free Press.

Huber, F., Hermann, A. \& Wricke, M. 2001. Customer Satisfaction as an antecedent of price acceptance: results of an empirical study. The Journal of Product and Brand Management. Vol. 10, No. 3, pp.160-169.

Imrie, B.C., Cadogan, J.W. \& McNaughton, R. 2002. The service quality construct on a global stage. Managing Service Quality. Vol. 12, No. 1, pp.10-18.

Jensen, M.C. 2001. Value Maximisation, Stakeholder Theory, and the Corporate Objective Function. Social Science Research Network Electronic Library. [Web:] http://papers.ssrn.com/ sol3/results.cfm?nxtres=21 [Date of access 23 March 2002]

Johns, N. 2000. What is this thing called service? European Journal of Marketing, Vol. 33, No. 9/10, pp.958-973.

Kaplan, R.S. \& Norton, D.P. 1996. Using the Balanced Scorecard as a strategic management system. Harvard Business Review. January-February, pp.75-85.

Lau, R.S.M. 2000. Quality of work life and performance - an ad hoc investigation of two key elements in the service-profit chain model. International Journal of Service Industry Management. Vol. 11, No. 5, pp.422-437.

Ling, A. 2000. CRM : It's all about customer value. [Web:] http://www.netassets.co.za/netassets/sitewide/content/ direct/ 1,2275,654839-5232-0,00.html [Date of access 10 July 2000]

Mayring, P. 2000. Qualitative Content Analysis. Forum Qualitative Sozialforschung/Forum: Qualitative Social Research [On-line Journal], 1 (2). Available at: http://qualitativeresearch.net/fqs/fqs-e/2-00inhalt-e.htm [Date of access: June 6, 2001]

Mehta, S.C. \& Durvasula, S. 1998. Relationships between SERVQUAL dimensions and organisational performance in the case of a business-to-business service. Journal of Business \& Industrial Marketing, Vol. 13, No. 1, pp.40-53.

Miller, A. 1998. Strategic Management (Third Edition). Boston: McGraw-Hill.

Nalebuff, B.J. \& Brandenburger, A.M. 1996. Co-opetition. London : Harper Collins.

Newman, K. 2001. Interrogating SERVQUAL: a critical assessment of service quality measurement in a high street retail bank. International Journal of Bank Marketing. Vol. 19, No. 3, pp.126-139.

Normann, R. \& Ramirez, R. 1993. From value chain to value constellation: designing interactive strategy. Harvard Business Review. July-August, pp.65-77.

Obolensky, N. 2000. An inclusive approach moving the thinking forward. News from the centre. Tomorrow's Company. Spring/Summer Issue 6. 
Parasuraman, A. 1998. Customer service in business-to-business markets : an agenda for research. Journal of Business and Industrial Marketing. Vol. 13, No. 4/5, pp.309-321.

Parasuraman, A., Berry, L.L. \& Zeithaml, V.A. 1991. Refinement and reassessment of the SERVQUAL scale. Journal of Retailing. Vol. 67, No. 4, pp.420-50.

Parasuraman, A., Zeithaml, V.A. \& Berry, L.L. 1985. A conceptual model of service quality and its implication for future research. Journal of Marketing. No. 49, April, pp.41-50.

Parasuraman, A., Zeithaml, V.A. \& Berry, L.L. 1988. SERVQUAL: a multiple-item scale for measuring consumer perceptions of service quality. Journal of Retailing, Vol. 64, No. 1, Spring, pp.12-40.

Payne, A., Holt, S. \& Frow, P. 2000. Integrating employee, customer and shareholder value through an enterprise performance model: an opportunity for financial services. International Journal of Bank Marketing. Vol. 18, No. 6, pp.258-273.

Pels, J. 1999. Exchange relationships in consumer markets? European Journal of Marketing. Vol. 33, No.1/2, pp.19-37.

Philip, G. \& Hazlett, S. 1997. The measurement of service quality: a new P-C-P attributes model. International Journal of Quality \& Reliability Management. Vol. 14, No. 3, pp.260-286.

Pitt, L., Caruana, A. \& Berthon, P.R. 1996. Market orientation and business performance: some European evidence. International Marketing Review. Vol. 13, No. 1, pp.5-18.

Powell, T.C. 1995. Total quality management as competitive advantage: a review and empirical study. Strategic Management Journal. Vol. 16, pp.15-37.

Robinson, L. 1999 . Measuring service quality: current thinking and future requirements. Marketing Intelligence \& Planning. Vol. 1, No. 1, pp.21-32.
Samik-Ibrahim, R.M. 2000. Grounded Theory methodology as the research strategy for a developing country. Forum Qualitative Sozialforschung/Forum: Qualitative Social Research [On-line Journal], 1 (1). Available at: http://qualitative-research.net/fqs [Date of access: June 6, 2001].

Schorn, A. 2000. The "Theme-centered Interview.". A Method to Decode Manifest and Latent Aspects of Subjective Realities. Forum Qualitative Sozialforschung/Forum: Qualitative Social Research [On-line Journal], 1 (2). Available at: http://qualitative-research.net/fqs/fqs-e/2-00inhalt-e.htm [Date of access: June 6, 2001]

Silvestro, R. \& Cross, S. 2000. Applying the service-profit chain in a retail environment. International Journal of Service Industry Management. Vol. 11, No. 3, pp.244-268.

Soteriou, A. \& Zenios, S.A. 1999. Operations, Quality, and Profitability in the Provision of Banking Services. Management Science September, Vol. 45, Issue 9, pp.12211239.

Sureshchandar, G.S., Rajendran, C. \& Anantharaman, R.N. 2002. Determinants of customer-perceived service quality: a confirmatory factor analysis approach. Journal of Services Marketing. Vol. 16, No. 1, pp.9-34.

Wiersema, F. 1996. Customer Intimacy. London : Harper Collins.

Zeigenfuss, D.E. 2000. Developing an internal auditing department balanced scorecard. Managerial Auditing Journal. Vol. 15, No. 1, pp.12-19.

Zeithaml, V.A., Berry, L.L. \& Parasuraman, A. 1996. The behavioral consequences of service quality. Journal of Marketing. Vol. 60, April, pp.31-46. 